\title{
Taraxacum officinale Leaves Ethanolic Extract as Immunostimulatory Agent For Reducing Side Effect of Doxorubicin in Sprague Dawley Rats
}

\author{
Sri Kasianningsih, Erlina Rivanti, Ratih Hardika Pratama, Nanda Resa Pratama, \\ Muthi'Ikawati, Edy Meiyanto*
}

Cancer Chemoprevention Research Center, Faculty of Pharmacy, Universitas Gadjah Mada, Yogyakarta Jalan Sekip Utara 55281 (Telp. 02746492662 Fax. 543120)

\begin{abstract}
Doxorubicin as chemotherapeutic agent causes immunosuppresive. The aim for this study to determine the effect of ethanolic extract of Taraxacum oficinale (ETO) in immunity system of Sprague Dawley rat that induced by doxorubicin to observe the profile of immunity cells. Sprague Dawley rats were divided into five groups each groups contain five rats : control doxorubicin group, doxorubicin dose $4,67 \mathrm{mg} / \mathrm{kgBW}+$ ETO dose $1000 \mathrm{mg} / \mathrm{kgBW}$, doxorubicin dose $4,67 \mathrm{mg} / \mathrm{kgBW}+$ ETO dose $500 \mathrm{mg} / \mathrm{kgBW}$, control extract group, and without treatment. Then the number of leukocytes, lymphocytes and neutrophils were analyzed by hematology analyzer, whereas CD8+ T lymphocytes by flowcytometry. Results showed groups of doxorubicin combined with ETO dose $1000 \mathrm{mg} / \mathrm{kgBW}$ and $500 \mathrm{mg} / \mathrm{kgBW}$ increased the number of leukocytes, lymphocytes, neutrophils, cytotoxic CD8 + T cells T cells compared to control doxorubicin group. These data presents that etanolic extract of Jombang leaves has immunostimulatory activity and potential as co-chemotherapy agents. Molecullar mechanism underlaying it's immune activity need to be explored in detail.
\end{abstract}

Keywords : co-chemotheraphy, doxorubicin, immunostimulatory, in vivo Taraxacum officinale,

\section{INTRODUCTION}

Cancer is a disease caused by the growth of body tissue cells that abnormal and uncontrollable. The main treatment is mostly done to treat cancer such as surgery, radiation, and chemotherapy (Siahaan, 2005). However, prolonged use of chemotherapy can cause weakening of the immune system (Patel et al., 2006).

The use of doxorubicin as an chemotheraphy agent is considered effective (Frias et al., 2009). However, the use of doxorubicin was thinking about some side effects such as causing cardiotoxicity (Frias et al. 2009; Bustova, 2009), susceptible to disease, hair loss, and sore throat. In addition, doxorubicin also affects the immune system by reducing the expression of IL- $\alpha$, interferon production $\gamma$, natural killer cells (NK), lymphocyte proliferation, and the ratio of $\mathrm{CD} 4+/ \mathrm{CD} 8+$ (Zhang et al., 2005). Therefore, we need a compound that works synergy with doxorubicin, but can reduce the immunosuppressive side effects of doxorubicin.

Today, we've discovered various materials which otherwise could increase the body's resistance to a disease called as immunostimulant. Ethanolic extract of Taraxacum oficinale leaves (ETO) is reported able to increase the secretion of TNF- $\alpha$ and IL-1 (Kim et al., 2000; Koo et al., 2004). TNF- $\alpha$ works together with IL-1 as functional non-specific immunity (Baratawidjaja, 2006). Jeon et al. (2007) also figured out that ETO is able to influence the antiinflammatory response through the inhibition of synthesis of nitric oxide (NO) and inhibition of COX-2 expression.Therefore, ETO can be expected used as immunostimulatory for combination with doxorubicin (co-chemotherapy).

*Corresponding author e-mail: meiyan_e@ugm.ac.id 
The aim for this stydy to find alternative safe co-chemotherapy in cancer therapy and determine the effect of ETO on immune cells in Sprague Dawley rats induced by doxorubicin

\section{MATERIALS AND METHODS}

\section{Taraxacum officinale Extraction}

Taraxacum officinale leaves powder was obtained and determined by B2P2TO2T (Balai Besar Penelitian dan Pengembangan Tanaman Obat dan Obat Tradisional) Tawangmangu, Central Java. Powder of Taraxacum officinale leaves $(1000 \mathrm{~g})$ was extracted with $70 \%$ ethanol $\left(\begin{array}{ll}10 & 1\end{array}\right)(1: 10 \mathrm{~b} / \mathrm{v})$. Ethanolic filtrate then concentrated by a rotary evaporator, followed by freeze drying to obtain viscous extract $(150.7 \mathrm{~g})$.

\section{Animals}

Female, 60 days old, Sprague Dawley, weighed from 90 to $120 \mathrm{~g}$ were purchased from UPHP UGM. Animals were raised in ambient temperature $\left(25-30^{\circ} \mathrm{C}\right)$, fed with pellet and tap water.

\section{Design of Experiments}

There were 5 groups, containing 4 rats in each group. Concentrated extract was suspended in $0.5 \% \mathrm{CMC}-\mathrm{Na}$, before being given to the animals orally for 7 consecutive day. Doxorubicin (Kalbe Farma) 4,67 mg/kgBW were administered on intra peritoneal (i.p.) twice a week in day $1^{\text {st }}$ and $4^{\text {th }}$, while ETO were given everyday for a weeks.

The first group acts as positive control, being treated with Doxorubicin (Doxo control group). The second group was treated with Doxorubicin and ETO $500 \mathrm{mg} / \mathrm{kgBW}$ (treatment group). The third group was treated with Doxorubicin and ETO $1000 \mathrm{mg} / \mathrm{kgBW}$ (treatment group). The fourth was treated with ETO 1000 $\mathrm{mg} / \mathrm{kgBW}$ (ETO control), and the fifth group was controlled without treatment. Each rat blood sampled two times, on day 0 (pre-treatment) and the $8^{\text {th }}$ (post-treatment) through the venous ocularis using heparinized capillaries and stored in EDTA vacutainers. Then the number of leukocytes, lymphocytes and neutrophils were determined by hematology analyzer, whereas CD8+ lymphocytes by flowcytometry.

Furthermore, sample preparation is performed 5,0 $\mu \mathrm{l}$ whole blood plus $10 \mu \mathrm{L}$ reagent rat antigen CD3 fluorescein isothiocyanate (FITC)
(Invitrogen) and phycoerythrin (PE) anti-rat $\mathrm{CD} 8+$ (eBioscience) and then vorteks and stored in a dark room for 15 minutes. After that, plus $450,0 \mu 1$ lysing solution (BP FACS) for dilution, vorteks, then set aside in a dark room for 15 minutes. The sample is measured by flowcytometer (FacsCalibur) and analyzed using the program multiset. The data was obtained from relative number of $\mathrm{CD} 8+\mathrm{T}$ cell lymphocytes.

\section{Statistical Methods}

SPSS/PC 13.0 software was used. Multiple comparisons were done using one-way ANOVA followed by Tuckey Test. The 0.1 level of probability was used as the criterion for significance.

\section{RESULT}

The effects of doxorubicin and/or ETO on the leukocytes, lymphocytes, neutrophils, and CD8+ T cell lymphocytes female Sprague Dawley rats (Figure 1). In general, the profile of hematology analyzer and flowcytometry after treatment in the control doxorubicin group, doxorubicin+ETO 1000, doxorubicin+ETO 500 showed decreasing both the number of leukocytes, lymphocytes, neutrophils, and $\mathrm{T}$ cell lymphocytes, CD8+ rather than pre-treatment, whereas the control group ETO 1000 and without treatment showed increasing both the number of leukocytes,lymphocytes, neutrophils, and CD8+ T cell than pretreatment.

Administration of doxorubicin give highest decreasing in the number of immune cells. It's showed that doxorubicin has immunosuppressive effects (Zhang et al., 2005). Treatment of doxorubicin in combination with ETO 1000 $\mathrm{mg} / \mathrm{kgBB}$ and ETO $500 \mathrm{mg} / \mathrm{kgBB}$ increased more the number of immune cells than doxorubicin control group. It showed that the combination of doxorubicin with ETO could reduce the side effects of doxorubicin in suppressing immune system.

The control extract group and the untreated groups of post-treatment showed an increase both the number of leukocytes, lymphocytes, neutrophils, and $\mathrm{CD} 8+\mathrm{T}$ cells rather than pre-treatment (baseline). Improvement in the control extract groups was higher than the without treatment group showed that the ability to reduce immunosuppressive effects on doxorubicin combined with ETO is caused by the capability of ETO to enhance the immune system (immunostimulatory). Variation of does showed 
that RTO $500 \mathrm{~m} / \mathrm{kgBW}$ decrease the number of immune cells is lower than ETO $1000 \mathrm{~m} / \mathrm{kgBW}$. It means that at a dose of $500 \mathrm{mg} / \mathrm{kgBW}$ combination of doxorubicin with ETO is more effective in suppressing the side effects of immunosuppressive doxorubicin. So, the effectiveness in reducing the immunosuppressive effects are non depending dose.

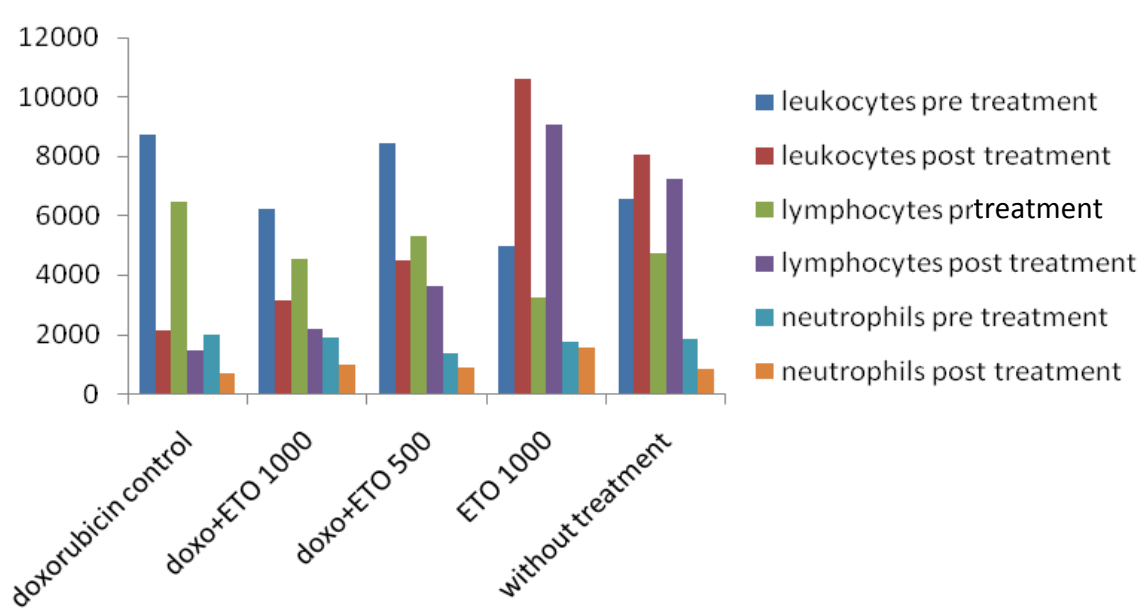

Figure I. Hematology Analyzer Profile leukocyte immune cell parameters leukocytes(a), lymphocytes (b), neutrophils (c), flowcitometry profile of CD8 + T cell lymphocytes (d),. In general, the profile of Hematology Analyzer and flowcytometry after treatment in the control group doxo, doxo + ETO 1000 , doxo + ETO 500 showed a decrease both the number of leukocytes, lymphocytes, neutrophils, and T cell lymphocytes, CD8 + rather than pre-treatment, whereas the control group ETO 1000 and without treatment showed increasing both the number of leukocytes, lymphocytes, neutrophils.

Table I. The number of cells leukocytes, lymphocytes, neutrophils

\begin{tabular}{|c|c|c|c|c|c|c|}
\hline & \multicolumn{2}{|l|}{ Leukosit $(/ \mu \mathrm{l})$} & \multicolumn{2}{|l|}{ Limfosit $(/ \mu \mathrm{l})$} & \multicolumn{2}{|c|}{ Neutrofil $(/ \mu \mathrm{l})$} \\
\hline & 'e treatment ost & tment & e treatment & ment & e treatment & ost treatment \\
\hline Doxo $4,67 \mathrm{mg} / \mathrm{kgBW}$ & 8475 & 2125 & 6475 & 1450 & 2000 & 675 \\
\hline Doxo+ETO 500 mg/kgBW & 6200 & 3125 & 4525 & 2175 & 1875 & 950 \\
\hline Joxo+ETO 1000 mg/kgBW & 8433 & 4467 & 5325 & 3600 & 1333 & 867 \\
\hline ETO $1000 \mathrm{mg} / \mathrm{kgBW}$ & 4975 & 10600 & 3225 & 9075 & 1750 & 1525 \\
\hline without treatment & 6550 & 8025 & 4700 & 7225 & 1850 & 800 \\
\hline
\end{tabular}


This result is supported by flowcytometry profiles of $\mathrm{CD} 8+\mathrm{T}$ cells lymphocytes relative (Fig. 2 and 3). In general, the fluorescence of lymphocytes CD8+ $\mathrm{T}$ cells (green fluorescence) generated in the post-treatment of all groups was smaller than pre-treatment. The fluorescence of doxorubicin smallest in the control group. Group combination of doxorubicin $500 \mathrm{mg} / \mathrm{KgBW}$ and $1000 \mathrm{mg} / \mathrm{kg}$, extract control groups and without treatment groups showed higher fluorescence than control doxorubicin group. The green fluoresence indicates the relatyve number of $\mathrm{CD} 8+\mathrm{T}$ cell lymphocytes. Then, the relatyve number of CD8+ $\mathrm{T}$ cell lymphocytes time with the total of lymphocytes (Table 1).

Result shows groups of doxorubicin combined with ETO $1000 \mathrm{mg} / \mathrm{KgBW}$ and 500 $\mathrm{mg} / \mathrm{KgBW}$ have the increas the number of leukocytes, lymphocytes, neutrophils, cytotoxic CD8+ $\mathrm{T}$ cells compared to control doxorubicin groups. But, only doxorubicin combined with ETO $500 \mathrm{mg} / \mathrm{KgBW}$ treated group has cytotoxic CD8+ $\mathrm{T}$ cells differs significantly from control doxorubicin. Based on these data, we can conclude that administration of ETO is able to increase the number of leukocytes, lymphocytes, neutrophils, the number of CD8+ $\mathrm{T}$ cell lymphocytes. The administration can give a single ETO and a combination with doxorubicin showed immunostimulatory activity which also can reduce the side effects of chemotherapy that can be used as a with agent chemotheraphy.

\section{Pre}

Treatment
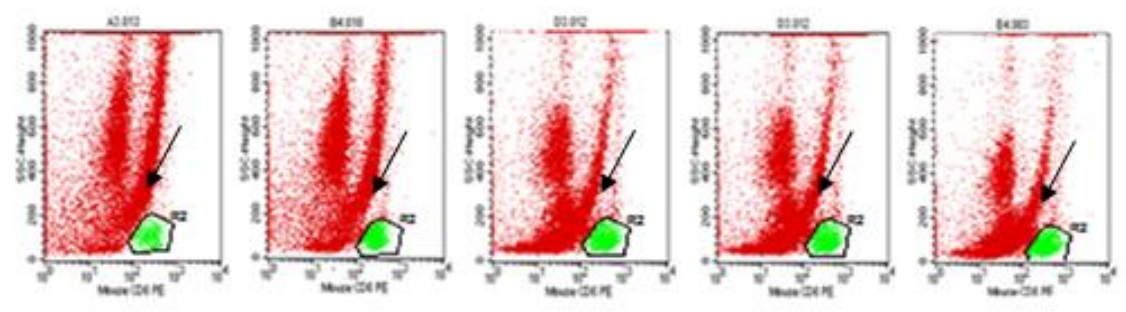

Post

Treatment
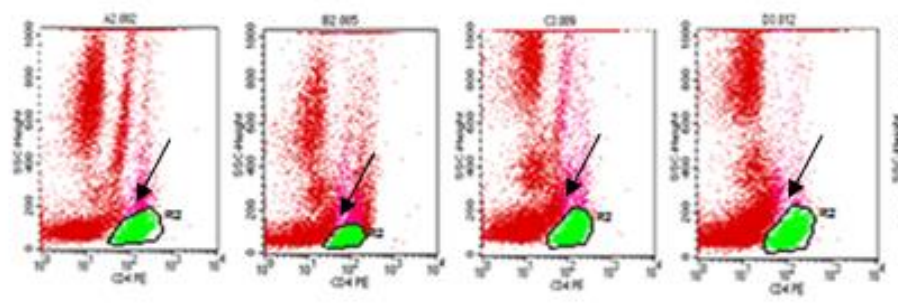

(a) doxo

(c)Doxo+ETO500

(d) ETO 1000

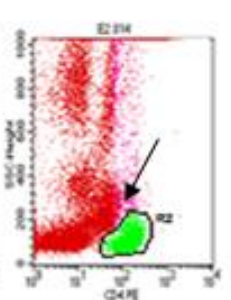

(e) KTP
(b)Doxo+ETO 1000

Figure 2. Results of data processing flowcytometry CD8 + T cell lymphocytes post-treatment with the multiset. Control doxo group (a); doxo + ETO 1000 (b); doxo + ETO 500 (c); ETO 1000 (d), without treatment (e) on the post treatment has a fluorescence that decreasing from pretreatment. $\rightarrow$ green fluorescence indicates the number of CD8 T cell lymphocytes. 
Table 2. The number of CD8+ $T$ limfosit cells

\begin{tabular}{|c|c|c|}
\hline \multirow{2}{*}{ Group } & \multicolumn{2}{|c|}{$\mathrm{CD} 8+(/ \mu \mathrm{l})$} \\
\hline & $\begin{array}{r}\text { Pre } \\
\text { reatment }\end{array}$ & Post treatment \\
\hline Doxorubicin & 930 & 76,6 \\
\hline Doxorubicin+ETO 1000 & 518 & 112 \\
\hline Doxorubicin+ETO 500 & 374 & 335 \\
\hline ETOI000 & 326 & 776 \\
\hline Without treatnent & 515 & 618 \\
\hline
\end{tabular}

\section{DISCUSIONS}

Doxorubicin is one of the most active cytotoxic agents in current use. The clinical efficacy of the anthracycline, however, has been precluded by immunosupresion (Zhang et. al., 2005). Free radical generation and lipid peroxidation have been suggested to be responsible for doxorubicin-induced immunosupression (Gewirtz, 1999).

In this study prior administration of ETO for twice a week of doxorubicin

notably increase the number of the immune cells of female Sprague Dawley rats. Doxorubicin administration induced immunosuppresion as manifested by highest decreasing in the number of immune cells.

Being polyphenolic compounds, flavonoids have shown anti-radical and iron-chelating properties in experimental animals (Quiles et. al., 2002), and thus would be possible protectors against anthracylines-induced immunosupression. T. officinale is a source of flavone, luteolin and luteolin-3-o-glucoside (Chun and David, 2005). Hu and Kitts (2005) reported that $T$. officinale flower extract suppreses both reactive oxygen species and nitro oxide and peroxidation lipid in vitro. Our findings showed that combination doxorubicin with ETO can reduce immunosuppresion effect of doxorubicin.

This research data can be used as one of the scientific evidence for the development of Taraxacum officinale leaves become phytopharmaca and standardized.

\section{CONCLUSION}

Taraxacum officinale leaves ethanolic extract $500 \mathrm{mg} / \mathrm{kgBW}$ is potentially to develop as immunostimulatory agent for co-chemotheraphy with doxorubicin.

\section{REFERENCES}

Baratawidjaja, K.G., 2006, Imunologi Dasar, Balai Penerbit fakultas Kedokteran Universitas Indonesia.

Bustová, I., 2009, Risk of Cardiotoxicity of Combination Treatment Radiotherapy and Chemotherapy of Locally Advanced Breast Carcinoma Stage III, Clin Onkol., 22(I), I721.

Frias, M.A., Lang, U., Gerber-Wicht, C., James, R.W., 2009, Native and Reconstituted HDL Protect Cardiomyocytes from DoxorubicinInduced Apoptosis, Cardiovasc Res., 25(6), 36-42.

Gewirtz, D.A., 1999, A Critical Evaluation of The Mechanisms of Action Proposed for The Antitumor Effects of The Anthracycline Antibiotics Adriamycin and Daunorubicin, Biochem Pharmacol, 57, 727-74I.

$\mathrm{Hu}, \mathrm{C}$. and Kitts, D.D., 2005, Dandelin (Taraxacum officinale) flower Extract Suppresses both Reactive Oxygen Species and Nitro Oxide and Lipid Peroxidation in Vitro, Phytomedicine, I 2(8), 588-597.

Jeon, H.J., Kang, H.J., Jung, H.J., Kang, Y.S., Lim, C.J., Kim, Y.M. and Park, E.H., 2008, AntiInflamantory Acitvity of Taraxavum officinale, J Ethnopharmacol, 4, I I5(I), 82-88.

Kim, H.M., Shin, H.Y., Lim, K.H., Ryu, S.T., Shin, T.Y., Chae, H.J., Kim, H.R., Lyu, Y.S., An, N.H. and Lim, K.S., 2000, Taraxacum officinale Inhibits Apha Production from Rat Astrocytes, Immunopharmacol Immunotoxicol, 22(3), $519-530$.

Koo, H.N., Hong, S.H., Song, B.K., Kim, C.H., Yoo, Y.H. and Kim, H.M., 2003, Taraxacum officinale Induces Cytotoxicity through TNFAlpha and IL-I Secretion in Hep G2 Cells, Life Sci, I6, 74(9), I I49-I I 57. 
Patel, A., Smith, H.J., and Sturzebecher, J., 1998, Design of Enzime Inhibitors as Drugs, Intoduction to The Principles of Drug Design ang action edited by $\mathrm{H}$. John Smith, Harwood Academic Publisher, Australia.

Siahaan, R., 2005, Terapi Biologi Kanker, from $w w w \cdot h u m a n m e d i c i n e \cdot n e t / ? s=$ article $\& m=$ rea d\&id=254 accesed September 2008.
Zhang, Xiao-Yu, Li, Wen-Guang, Wu, YongJie, Gao, and Ming-Tang, 2005, Amelioration of Doxorubicin-Induced Myocardial Oxidative Stress and Immunosuppression by Grape Seed Proanthocyanidins in Tumour-Bearing Mice, Journal of Pharmacy and Pharmacology, 57(8), I043-1052. 